\title{
Narraciones de derechos: educación social, ética y deontología profesional
}

\author{
Narrations of rights: social education, ethics and \\ professional deontology \\ Narrativa direitos: educação social, ética e deontologia profissional
}

\author{
Víctor Manuel Martín Solbes y Eduardo Salvador Vila Merino \\ UNIVERSIDAD DE MÁLAGA
}

\begin{abstract}
No creo que sea obligatorio que la ética lo obligue a uno a estar constantemente diciendo impertinencias, pero es casi seguro que antes o después vas a resultar impertinente.

I do not think it obligatory that ethics needs one to constantly make impertinant remarks, but it is almost certain that, sooner or later, one will appear impertinant.

Savater, F., (1999): La educación es el momento adecuado de la ética.
\end{abstract}

\section{Resumen}

La educación social, como toda forma de acción pedagógica, tiene adosadas una serie de consideraciones ineludibles de orden ético. Por esta razón, en los últimos años se han incrementado las propuestas de sistematización y construcción de una ética aplicada y contextualizada a las especificidades de la educación social. En este artículo pretendemos adentrarnos en estas aproximaciones, que desde nuestro punto de vista constituyen una suerte de narraciones en tránsito, en el sentido de que suponen espacios de reflexión colectivos en continua reconstrucción y perfeccionamiento, como todo conocimiento social, lo cual no implica que dejen de ser referen-

\section{Summary}

Social education, like all forms of education, contains a series of inevitable ethical considerations. For this reason proposals have recently increased for the systemization and construction of applied ethics in the context of social education. The aim of this article is to look at these approaches on a deeper level. We consider these approaches constitute a kind of narrative in transit, in the sense that they represent areas of collective reflections which, as with all social knowledge, are in a continual process of reconstruction and development. Nevertheless, these reflections should be a reference for the improvement 
tes de necesaria asunción para la mejora de las iniciativas teóricas y prácticas relacionadas con la educación social.

Así, comenzamos analizando el sentido que desde la educación social supone la distinción entre ética y moral, de manera que esto nos permita iniciar la búsqueda de códigos comunes para la profesionalización de la educación social con rango deontólogico propio, por lo que nos centramos en avanzar aspectos definitorios vinculados al hecho de entender la ética como eje para narrar la educación social como punto de encuentro de sentido y experiencia con características diferenciadoras desde lo normativo y deontológico. A continuación, nos adentramos en describir el histórico reciente de la disciplina desde la óptica de los distintos desarrollos de un código deontológico propio, explicitando sus puntos esenciales y realizando una propuesta concreta de aplicación de los mismos, vinculando la educación social con procesos éticos y políticos irrenunciables en el desarrollo ciudadano.

PALABRAS CLAVE: educación social, ética, deontología profesional, compromiso político, desarrollo ciudadano.

\section{Resumo}

Educação social, como qualquer forma de ação pedagógica, que tem se inclinou para uma série de considerações inevitáveis, a fim ética. Por isso, nos últimos anos, propostas de sistematização e construção de uma ética aplicada e contextualizada na educação social têm aumentado. Neste artigo queremos aprofundar essas aproximações que, sob nosso ponto de vista, compõem uma espécie de narrações transitorial no sentido de que eles significam salas de reflexões coletivas em constante reconstrução e melhoria, como todo conhecimento social, o que não implica que deixam de ser referentes pressuposto necessário para melhorar as iniciativas teóricos e práticos relacionados com a educação social. of theoretical and practical initiatives in social education.

We begin by analyzing the way in which social education makes the distinction between the ethical and the moral. This allows us to begin the identification of common codes for the professionalization of social education with its own professional ethics. Therefore, we concentrate on finding definitive aspects related to the understanding of ethics as the axis with which to narrate social education as being a meeting point for meaning and experience, with differing characteristics regarding normatives and professional ethics. Following this, the recent history of the discipline is described, focusing on the varying developments of a professional code of ethics. The essential points are explained with concrete proposals for its implemention. Social education is linked to ethical and political processes, both indispensable in the development of citizenship.

KEY WORDS: Social Education, ethics, professional ethics, political commitment, development of citizenship.

\section{Resumo}

Educação social, como qualquer forma de ação pedagógica, que tem se inclinou para uma série de considerações inevitáveis, a fim ética. Por isso, nos últimos anos, propostas de sistematização e construção de uma ética aplicada e contextualizada na educação social têm aumentado. Neste artigo queremos aprofundar essas aproximações que, sob nosso ponto de vista, compõem uma espécie de narrações transitorial no sentido de que eles significam salas de reflexões coletivas em constante reconstrução e melhoria, como todo conhecimento social, o que não implica que deixam de ser referentes pressuposto necessário para melhorar as iniciativas teóricos e práticos relacionados com a educação social. 
Assim, começamos analiyzing o significado que, desde a educação social, supõe a diferença entre ética e moral, na forma como nos permitir iniciar a busca de novos códigos para a profissionalização da educação social com o seu próprio posto de deontologia, para que estão focados em aspectos aduancing Definitório ligados ao fato de ética compreensão como um eixo de relacionar educação social como um ponto de encontro de sentido e experiência com Características de distintivos do normativo para o deontológicas. Em seguida, mergulhar para descrever a história final da disciplina objeto do ponto de vista da evolução diferentes de um código adequado deontológicas, afirmando explícitos seus pontos essenciais e fazer uma proposta concreta de sua aplicação a educação, a ligação social com un processo renunciable ética e política, civil desenvolvimento

PALAVRAS-CHAVE: educação social, ética, deontologia profissional, compromisso político, o desenvolvimento cívico.

\section{La ética como referente para narrar la edu- cación social}

Al igual que el lenguaje configura el pensamiento, las palabras nos hacen, deshacen y rehacen. Y esto es así porque narramos la realidad desde nuestras relaciones con los otros y con nosotros mismos; narraciones que constituyen un tipo especial de discurso comunicativo que nos sirve para pensar, organizar el conocimiento e interpretar(nos) y que emergen como particulares reconstrucciones de la experiencia humana, individual o colectiva, por las que se le da sentido a la misma y donde la argumentación y el tiempo configuran el significado. Y en dicha estructura es el lenguaje el que media la experiencia y la acción, como adelantara Vigotsky (2000) al hablar de la mediación semiótica del funcionamiento psíquico y de cómo se produce la recons-
Assim, começamos analiyzing o significado que, desde a educação social, supõe a diferença entre ética e moral, na forma como nos permitir iniciar a busca de novos códigos para a profissionalização da educação social com o seu próprio posto de deontologia, para que estão focados em aspectos aduancing Definitório ligados ao fato de ética compreensão como um eixo de relacionar educação social como um ponto de encontro de sentido e experiência com Características de distintivos do normativo para o deontológicas. Em seguida, mergulhar para descrever a história final da disciplina objeto do ponto de vista da evolução diferentes de um código adequado deontológicas, afirmando explícitos seus pontos essenciais e fazer uma proposta concreta de sua aplicação a educação, a ligação social com un processo renunciable ética e política, civil desenvolvimento

PALAVRAS-CHAVE: educação social, ética, deontologia profissional, compromisso político, o desenvolvimento cívico.

\section{Ethics as a reference to narrate social edu- cation}

Just as language shapes thought, so words make us, unmake us and remake us, since we narrate reality according to our relations with others and with ourselves. These narratives constitute a communicative discourse of a special kind, enabling us to reflect, organize knowledge, interpret and self-interpret, and which emerge as personal remakings of individual or collective human experience. Through narratives we make sense of experiences and where reasoning and the historical time form meaning. It is in this structure that language that mediates experience and action, as Vigotsky (2000) stated when referring to the semiotic mediation of mental functioning and how the reconstruction of external 
trucción de las formas discursivas externas mediante procesos de internalización.

El conocimiento pedagógico social constituye también una narración. Por tanto, acudir a la narratividad como esencia expresiva en la construcción del conocimiento educativo sugiere una serie de principios, tales como los relacionados con la comunicatividad como aspiración y necesidad, la explicitación de su carácter subjetivo y de construcción socialmente configurada o sus pretensiones de validez intersubjetiva y vocación transformadora. De esta manera, si consideramos que el sentido e inteligibilidad de la educación social debe venir dado por la explicitación de las intenciones, motivos y propósitos que tiene, damos un paso más hacia la representación de las políticas educativas desde sus posibilidades narrativas en la práctica, las cuales se dirigen a describir e interpretar sus características distintivas para comprender cómo le damos sentido a lo que hacemos y cómo podemos plantear los cambios sobre lo que no queremos (en este caso, medidas que excluyan y mengüen el derecho a la educación). Así, la educación social cobra significado real desde su lenguaje de posibilidad y creatividad, de no convertirse en conocimiento muerto ni aportar nada social o políticamente. Sin olvidar tampoco, en todo este proceso, que toda narración tiene un sujeto narrador, lo cual implica que no podamos obviar que detrás del conocimiento se encuentra el sujeto que conoce, el cual tiene su propia biografía, influencias culturales, prejuicios sociales, estereotipos formativos, experiencias vitales, etc.

Por estas razones, aparte de sus implicaciones para la investigación educativa y las grandes narrativas de emancipación pedagógicas, consideramos que lo narrativo también se puede desarrollar de manera que la reflexión que suponga, se establezca desde y hacia la práctica. Y una de las formas que nos puede permitir esto, es la prácica de discursos que, construidos de manera metafórica, promuevan el debate, generen discusión, re- speech forms is produced through internal processing.

Social educational knowledge also constitutes a narrative. Therefore, in turning to narrativity as the expressive essence in the construction of educational knowledge, a series of principles arise regarding communicativeness as an aspiration and a necessity, the explanation of its subjective nature, its socially-composed construction, or its claims of intersubjective validity and transforming vocation. In this way, if we consider that the significance and intelligibility of social education can be understood through an explanation of its inherent intentions, motives and purposes, then we progress towards a vision of educational policies seen from their possibilities in practice. This leads us to describe and interpret its distinctive characteristics in order to understand how we give meaning to what we do and how to approach changing the undesirable (in this case measures which exclude and reduce the right to education).Thus, social education takes on a real significance through its language of possibility and creativity, thereby avoiding the danger of becoming old knowledge, with nothing to offer either socially or politically. Neverthless, we must not overlook the fact that each narative has its narrator, with the inevitable inplication that behind each piece of knowledge there is a subject in possesion of that knowledge with their own biography, cultural influences, social prejudices, educational stereotypes, life experiences, etc.

For this reason we believe that the narrative can also be developed in a way that the resulting ideas emerge from, and works towards, a practical application. This, besides its implications for educational investigation and the great narratives of educational emancipation. One of the ways which allows us to do this is through discourse, which, constucted in a metaphorical manner, promotes debate, generates di- 
muevan emociones, produzcan potencialmente una capacidad de adhesión, asunción e internalización por parte de las personas implicadas o que se vean reflejadas en los mismos o, simplemente, nos permitan pensar en nuestra realidad educativa global y analizarla con nuevos elementos o al menos con una perspectiva algo distinta, para lo cual el papel de la educación social resulta fundamental, ya que supone también una forma de narrar la alteridad de los otros/as para narrarnos así a nosotros mismos/as, intentando poner de manifiesto, contextualizadamente, lo expresado por Dussel y Apel (2005: 362):

Quien actúa críticamente con validez antihegemónica, desde el reconocimiento de la dignidad de las víctimas como sujetos éticos, desde el conocimiento de la imposibilidad de vivir de los propios dominados, y desde la no-participación en la argumentación de los excluidos, ya siempre está obligado in actu a la responsabilidad que comparte solidariamente, a estudiar las causas de la victimización de los dominados y a proyectar alternativas positivas futuras para transformar la realidad.

Esto nos debe permitir analizar situaciones cotidianas que se nos presentan desde las pautas marcadas en nuestra propia agenda educativa, explicitar factores emocionales a los que no podemos ser ajenos desde el análisis político y evaluativo (no olvidemos el carácter intrínsecamente ético de la dimensión política del ser humano, en concreto como asunción de lo colectivo inherente a la interpelación ética implícita en la presencia del otro/a social), percibir cómo puede condicionar nuestro quehacer educativo y reflexionar sobre él desde y con otra mirada, evitando también las visiones dicotómicas, siendo conscientes de que la realidad es más compleja, pero partiendo de su potencialidad para un debate público absolutamente necesario (Vila, 2005). alogue, stirs emotions, potentially produces unity, comprehension and internalization by the persons implicated, or who see themselves reflected in the same. In addition it allows us to consider our the reality of global education and analyze it afresh or, at least, from a different perspective. For this, the role of social education plays a fundamental part, since it implies a way of narrating the otherness of fellow beings, in order to narrate ourselves to ourselves and try, in context, to demonstrate the views of Enrique Dussel (2005:362).

Those who act critically and from an anti-hegemonic standpoint, who recognize the dignity of victims to be treated as ethical subjects, aware of the impossiblity of living as a dominated individual and who take no part in the reasonings of exclusion, are obliged to act in accordance with their responsibilities of shared solidarity, to study the causes of the victimization of the suppressed, and should work to find alternative positive futures to transform the reality.

This should allow us to analyze the everyday situations we face, according to the guidelines set in our personal educational agenda and explain the emotional factors we cannot ignore when making a political and evaluative analysis (not forgetting the political side of human nature, which is intrinsically ethical, and in particular the assumption of the collective, inherent in the ethical challenge implicit in the presence of another social person). Furthermore, it should make us aware of how our educational work can be conditioned and reflect on this from a different perspective, avoiding dichotomous viewpoints and conscious that, although the reality is more complex, essential public debate should stem from this potential base.

NARRACIONES DE DERECHOS:EDUCACIÓN SOCIAL, ÉTICA Y DEONTOLOGÍA PROFESIONAL [ 307 ] SIPS - PEDAGOGÍA SOCIAL. REVISTA INTERUNIVERSITARIA [1139-1723 (2012) 20, 303-323] • TERCERA ÉPOCA 


\section{2. ¿Por qué vincular ética y educación social?}

Desde esta narración implícita en la educación social emerge también una consideración necesaria en torno a las preocupaciones de orden ético, vinculada a la misma. En este sentido, debemos comprender que la ética se relaciona con los actos morales y con las prácticas humanas. Etimológicamente, la ética, procede del término griego ethikos, que podemos traducir por carácter. Así, la ética determina cómo debemos actuar los miembros de una sociedad o, en nuestro caso, los que ejercemos una profesión.

En general, la ética profesional pretende regular las actividades a una profesión, mientras que el código deontológico, también denominada ética normativa, implica una serie de principios de obligado cumplimiento. Así, la ética orienta las actuaciones deseables de una profesión, mientras que el código deontológico debe garantizar que la profesión se ejerza de manera ética. Así pues, la ética supone un conjunto de principios que guían las relaciones humanas y que deben ser universales, válidos para todas las personas y duraderos en el tiempo; en este sentido, los derechos humanos tienen mucho que ver con la ética, por lo que tiene sentido en esta articulación hablar de narraciones de derechos.

En nuestras actuales sociedades vivimos una moral individualista que se justifica desde las mayorías académicas, políticas y liberales; desde estas perspectivas buscamos el bien propio, lo que nos conviene individualmente (Guisán, 2001), olvidando con demasiada facilidad que los demás también existen y que es necesario que nos preocupemos del bienestar, la autonomía y la libertad de los otros y otras. Así, cada miembro de la sociedad mantiene una representación de la realidad que se encuentra asociada a un previo planteamiento ideológico. $\mathrm{Y}$ es ahí donde deben originarse proyectos de intervención socioeducativa para el cambio y la transformación social, ya que la praxis de la educadora y del educador so-

\section{Why link ethics and social education?}

From the narration implicit in social education, there arise some closely related ethical issues. In this sense we comprehend ethics as being related to moral acts and human practices. The word 'ethics', from the Greek 'ethikos', meaning 'character', determines how members of society should act, or, as in our case, how members of a profession should carry out their work.

In general, professional ethics seeks to regulate professional activities while the deontological code, or code of ethics, implies a series of binding principles. In this way, ethics provides the orientation for what is desirable in a profession, whereas the code of ethics ensures that a profession is carried out in an ethical manner. Therefore, ethics implies a set of principles which guide human relations and which, moreover, should be universal, valid for all people and for all time. In this sense, human rights are closely linked to ethics and which is why, in this article, it is reasonable to speak of the narratives of human rights.

In present day societies, the prevailing condition is one of Ethical Egoism, vindicated by the academic, political and liberal majorities. This line of thought implies that one should always act in one's own best interest (Guisan, 2001), forgetting all too readily that others also exist and that it is necessary to seek the well-being, autonomy and freedom of the rest. It could therefore be argued that each member of society maintains a vision of reality which is associated to a previous idealogical position. This is precisely where projects for the change and transformation of society by social educators should originate, since educators' codes of practice should be grounded in deep reflections concerning those values which guide our actions. Furthermore, it is through these reflections, transmitted through social education, that 
cial debe originarse tras el planteamiento de profundas reflexiones sobre estos valores que guían nuestra acción. Y es a través de estas reflexiones, vehiculadas desde la educación social, desde las que pretendemos realizar aportaciones que permitan cambiar la realidad, ya que deseamos iniciar una vía de intervención integral y permanente con las personas y $\mathrm{co}^{-}$ lectivos para que asuman responsabilidad, dando, de alguna manera, respuestas a la urgente necesidad de una acción educativa en los entornos segregados y excluidos. Asimismo, desde la educación social, intentamos abordar los factores culturales, sociales y educativos que ayuden a las personas a dejar de percibirse a sí mismas como integrantes de colectivos excluidos.

Pues bien, la práctica profesional desde la educación social tiene mucho que ver con una responsabilidad social, por lo que es necesaria la elaboración, conocimiento por parte de los profesionales e implementación de un código ético en nuestras actuaciones. Creemos que cualquier código ético, y por supuesto, el del educador y de la educadora social, deben basarse en la consecución, de al menos, las siguientes competencias (Hirsch, 2010):

- Cognitivas, referidas, entre otras cuestiones, a los conocimientos científicos, metodológicos, legales.

- Técnicas, que recogen habilidades técnicas que permitan aplicar los conocimientos.

- Sociales, referidas a una serie de habilidades sociales que incluyen las capacidades de interacción y colaboración tanto con personas como con instituciones.

- Éticas, que tratan del saber profesional, y que incluyen valores, actitudes y estilos de comportamientos.

- Afectivo-emocionales, vinculadas a los sentimientos y a la manera de posicionarse respecto a los demás.

De este modo, las competencias cognitivas, técnicas, sociales, éticas y afectivo-emo- we can attempt to provide opportunities with which to change the reality. Since we aim, through comprehensive and permanent intervention, to encourage people and groups to assume responsibility. This action also, in a way, provides an answer to the urgent need for educational action directed towards those groups experiencing segregation and exclusion. Similarly, through social education, our aim is to address cultural, social and educational factors that help individuals to avoid considering themselves members of excluded groups.

It follows therefore that the profession of social educator is closely connected to a social responsibility, making it necessary to formulate and implement an ethical code of which educators are fully aware. We consider that any ethical code and, particularly that of social educator, should be based on seeking to achieve aptitude in the following areas (Hirsch 2010):

- Cognitive. Concerning scientific, methodological and legal knowledge, among others.

- Technical. Referring to the ability to apply knowledge.

- Social. Regarding the ability to know how to behave in society, including skills in social interactions and the ability to collaborate with people and institutions.

- Ethics. Concerning the knowledge of professionals in the areas of values, attitudes and behaviour.

- Affective-emotional skills, related to feelings and behaviour towards others.

In this way cognitive competences, including technical, ethical, and affectiveemotional competences, should preside in all socially educative situations. Knowledge should be afforded, which, after being digested, serves to raise awareness and give people control over their own futures. From 
cionales, deben presidir las acciones abordadas desde la educación social y aportar conocimientos que se interioricen, para que las personas se conciencien y se empoderen de su vida, de su futuro, para que así, y desde su propia concienciación sean capaces de acometer los procesos de inclusión, tomados como el derecho de toda persona a incluirse en un tejido social, y no como una política social que admite la exclusión como un hecho normal, y por lo tanto, abocada al fracaso (Martín y Vila, 2007).

Siguiendo a Hirsch (op. cit) y desarrollando adecuadamente las competencias que señala, la educadora y el educador social puede convertirse en un modelo educativo potenciador del desarrollo moral de las personas con las que trabaja, teniendo muy en cuenta, tanto la libertad como la autonomía de las personas. Debe estar motivado en su quehacer profesional, y esta motivación debe ser percibida por las personas, porque las relaciones que se establezcan entre el educador o educadora social y el grupo de personas con las que trabaja, deben basarse en la libertad, el respeto y en los procesos tendentes a la autonomía y a la responsabilidad de las personas. El reto, por tanto, se encuentra en conocer cómo desde la educación social podemos dar respuestas a los procesos exclusores dentro del discurso de los derechos humanos para que las personas que sufren las consecuencias de esta exclusión no sean invisibles, por lo que debemos desligarnos de una cultura meritocrática que discrimina trascendiendo no solo los mecanismos de exclusión sino también los de integración, entendidos como adaptación de unas personas o colectivos a la cultura hegemónica dominante de manera acrítica, lo que nos debe llevar a optar por mecanismos dialógicos que promuevan la inclusión social desde los principios de la equidad y la justicia, analizando las contradicciones e injusticias que nuestro propio sistema genera con el fin de poder así combatirlas desde un cambio de paradigma social y una inquebrantable op- this awareness, inclusion should be encouraged and the inclusion of all members in society accepted as a human right for everyone. In addition, social policies, which see exclusion as something normal and, therefore, doomed to fail, should be rejected (Martin \& Vila, 2007).

Following Hirsch (op.cit), and with a proper undertaking of the various competencies outlined, the social educator may become a potential educative model for receivers of this education, bearing in mind at all times an individual's personal freedom and independence. The educator needs to be motivated in his profession and this motivation should be noticeable to all, since the relationship between the educator and students should be based on values of liberty and respect, while at the same time, encouraging independence and personal responsibility. The challenge facing us is that of discovering how solutions to the process of exclusion can be found, through social education and within the framework of human rights. It is necessary to give the excluded a voice and for that we need to detach ourselves from a meritocratic culture which discriminates unjustly, transcending not only the mechanisms of exclusion, but also those of inclusion which uncritically adapt people or groups to the dominant hegemonic culture. This should lead us to adopt mechanisms of dialogue promoting social inclusion based on principles of equality and justice. The contradictions and injustices of our society should be analyzed in order to address them using a social paradigm and in unwavering favor of disadvantaged groups. It is from this perspective that social education becomes significant, since following a code of professional ethics, a critical and committed standpoint needs to be adopted, based on dialogue, participation and ever mindful of human dignity. Therefore, the respon-

[ 310 ] - Víctor Manuel Martín Solbes y Eduardo Salvador Vila Merino

SIPS - PEDAGOGÍA SOCIAL. REVISTA INTERUNIVERSITARIA [1139-1723 (2012) 20, 303-323] TERCERA ÉPOCA 
ción a favor de las personas y colectivos más desfavorecidos, que es desde donde cobra sentido y sustantividad la perspectiva de la educación social, ya que en el desarrollo de la ética profesional es necesario que se produzca una reflexión crítica y comprometida con la práctica socioeducativa, basada en el diálogo, la participación y la dignidad humana. Así pues, la responsabilidad derivada del ejercicio profesional debe vincularse inevitablemente con el bienestar de los otros.

En cualquier caso, la ética profesional se relaciona con la idea del deber, la idea del bien y con la idea de sentido, ya que en el desarrollo profesional se pretende intervenir en un determinado ámbito social, procurando con esta actuación profesional el bien del destinatario, además de permitir la consecución de la propia profesión. De este modo, la profesión de la educación social no puede concebirse como algo neutro, en la que la conciencia no toma partido; muy al contrario, la profesión se convierte en un potenciador de compromisos sociales tendentes a la dignificación de la persona. De este modo, es necesario analizar y comprender el funcionamiento de nuestras sociedades globalizadas neoliberales, para así, como ciudadanos y educadores críticos, comprometidos con la deseada transformación social, para lo que es necesario ser conscientes de hasta qué punto las estructuras sociales y económicas condicionan nuestra vida y nuestras intervenciones educativas. Además, es necesario superar la visión y los planteamientos hegemónicos y homogenizadores de nuestras sociedades, donde no tiene una cabida real lo diferente, y trascender, desde estos planteamientos, los condicionantes sociales en los que estamos sumergidos, con la finalidad de generar una alternativa crítica, emancipadora y libre, que nos faculte, desde la ética, la praxis y el diálogo, colaborar en la construcción de unas relaciones basadas en la convivencia y en los valores democráticos, para conseguir un futuro más justo e igualitario. sibility arising from the profession of educator should inevitably be linked to ensuring the welfare of others.

This said, professional ethics are related to the idea of duty, of what is right and what is reasonable, since the educator intervenes in a certain social setting, aiming, through his professional acts, to obtain what is best for the receiver, besides achieving his professional goals. In this way, the profession of social educator cannot be seen as something neutral and in which conscience plays no part. On the contrary, the profession becomes a stimulant for social commitments containing tendencies for the promotion of personal dignity. Consequently, an analysis and understanding of the workings of our neoliberal globalized society is needed, so that citizens and critical educators, committed to a much-desired social transformation, can be made aware of how far social and economic structures condition our lives and educational interventions. In addition, it is necessary to overcome the hegemonic and homogenizing tendencies of our society, which do not tolerate differences, and transcend social conditioning, in order to create a critical alternative, which liberates and is free for all. This allows us, through the use of ethics, practices and dialogue, to collaborate in the construction of relations based on social harmony and democratic values, in order to obtain a future which is more just and more equal for all.

Furthermore, we should also bear in mind that, all too often, we focus less on the capabilities of a person or group and more on their shortcomings. This, from the very beginning, gives us a negative picture of the person with whom we are working. These capabilities should, nevertheless, be considered common to all humanity and from which an infinite number of possibilities could arise for people in an emo-

NARRACIONES DE DERECHOS:EDUCACIÓN SOCIAL, ÉTICA Y DEONTOLOGÍA PROFESIONAL [ 311 ] SIPS - PEDAGOGÍA SOCIAL. REVISTA INTERUNIVERSITARIA [1139-1723 (2012) 20, 303-323] • TERCERA ÉPOCA 
Por otra parte, debemos considerar que desde la educación social, en más ocasiones de las deseadas, acostumbramos a fijarnos en las carencias de las personas y colectivos, más que en sus capacidades, lo que, de entrada, proporciona una visión negativa de las personas con las que trabajamos. Sin embargo, debemos tener en cuenta estas capacidades porque son patrimonio de todo ser humano, y desde ellas se pueden proyectar las personas, emocional, educativa, social y políticamente hasta el infinito, conformándose así, un ciudadano responsable y competente.

Comprender el mundo en el que vivimos nos capacita desde nuestra ética y desde nuestra conciencia, para intervenir críticamente en él, a pesar de los posicionamientos inalterables e incuestionables que desde todas las esferas tratan de mantenernos inmóviles. Sin embargo, por coherencia personal y profesional, es necesario reivindicar nuestra conciencia política como soporte fundamental para la transformación social y la reconstrucción colectiva. Paulo Freire (2002: 67-68), lo expresó sabiamente:

"si, en realidad, las estructuras económicas me dominan de manera tan señorial; si moldeando mi pensamiento, me hacen objeto dócil de su fuerza, ¿cómo explicar la lucha política y, sobre todo, cómo hacerla y en nombre de qué? Para mí, en nombre de la ética, obviamente, no de la ética universal del mercado, sino de la ética universal del ser humano; para mí, en nombre de la necesaria transformación de la sociedad de la que se deriva la superación de las injusticias deshumanizadoras. Y todo ello porque, condicionado por las estructuras económicas, no estoy, sin embargo, determinado por ellas".

Una vez analizadas estas cuestiones generales y el compromiso social y personal que la ética le exige a la práctica profesional de la educación social, pasamos a analizar el desa- tional, educative, social or political sphere, thereby helping form responsible and competent citizens.

Ethics and our own conscience enable us to understand the world in which we live and to intervene in a critical way, despite the unalterable and unquestionable postures from all areas which try to maintain us immobile. However, for the sake of personal and professional congruency, it is necessary to revindicate our political conscience as the main base for bringing about social change and a rebuilding of collectives. Paolo Freire (2002: 67-68), sagely expressed this idea:

"If the ecomonic structures dominate me absolutely; if, by them shaping my thoughts, I am weakened against their power, then how can political struggle be explained? Above all, how can it be undertaken and to what aim? For me, in the name of ethics, obviously, although not the universal ethics of the market, but the universal ethics of humanity; for me, in the name of the necessary transformation of society which would produce the end of dehumanizing injustices. All this because, though conditioned by economical structures, I am not, however, determined by them".

Having analyzed these general issues, together with the social and personal commitments which ethics demands of social education, we move on to analyze the ethical development of the profession through its deontological code.

We know that, since the beginning of Social Education as a profession, there has been much internal debate among professionals regarding professional ethics. Interest was first shown during the celebration of the Primer Congreso del Educador Social (First Congress of the Social Educa-

[ 312 ] - Víctor Manuel Martín Solbes y Eduardo Salvador Vila Merino

SIPS - PEDAGOGÍA SOCIAL. REVISTA INTERUNIVERSITARIA [1139-1723 (2012) 20, 303-323] TERCERA ÉPOCA 
rrollo ético de la profesión a través de su código deontológico. Pues bien, podemos afirmar que desde los inicios de la Educación Social como profesión, ha existido un debate interno entre los profesionales, en torno a la ética profesional, aunque este interés se materializa en el año 1995, durante la celebración del Primer Congreso del Educador Social, celebrado en Murcia. Es a partir de 1996, cuando en diferentes seminarios, jornadas y congresos celebrados por todo el territorio nacional, las educadoras y los educadores sociales $\mathrm{CO}^{-}$ mienzan a trabajar sobre la ética profesional, siendo en el XV Congreso Mundial de la AIEJI, Asociación Internacional de Educadores de Jóvenes Inadaptados, y III Congreso Estatal del Educador Social, celebrado en Barcelona en 2001, cuando se asientan las bases y los compromisos para la elaboración de un código ético profesional. Este compromiso culmina con la aprobación en 2003 del Código Deontológico del Educador/a Social.

Fue en el año 2007 cuando la Asociación Estatal de Educación Social (ASEDES) y el Consejo General de Colegios de Educadoras y Educadores Sociales (CEES), culminan y publican un arduo trabajo en el que intentan definir lo que es la Educación Social, el Código Deontológico y el Catálogo de Funciones y Competencias de la Educadora y el Educador Social. A todo este trabajo se le denominó Documentos Profesionalizadores.

En estos Documentos se define la Educación Social como un derecho de la ciudadanía y como una profesión de carácter pedagógico generadora de contextos educativos y acciones mediadoras y formativas que posibilitan la incorporación de las personas a la sociabilidad y la promoción cultural y social (ASE$\mathrm{DES}, 2007)$. Aunque debemos señalar que este Documento Profesionalizador nace con la conciencia de estar inacabado ya que se encuentra abierto a nuevas reflexiones y aportaciones que lo mejoren. En cualquier caso, la ética se presenta como un componente básico de la responsabilidad, o mejor dicho, corresponsa- tor), in Murcia (Spain) 1995. In 1996, educators and social educators begin to work on professional ethics at different seminars, workshops and conferences held throughout the country.

At the $X V$ Congreso Mundial de la AIEJI, Asociación Internacional de Educadores de Jóvenes Inadaptados (XV World Congress of AIEJI, International Association of Maladjusted Children), and the III Congreso Estatal del Educador Social (Third State Congress of Social Educators), held in Barcelona (Spain) in 2001, the bases were set down, and the commitments laid out, for the development of a professional code of ethics. This commitment culminated in 2003, with the approbation of the Código Deontológico del Educador/a Social (Code of Ethics for Social Educators).

In 2007, the arduous task of defining Social Education was carried out by the Asociación Estatal de Educación Social (National Association of Social Educatio (ASEDES), and the Consejo General de Colegios de Educadoras y Educadores Sociales (General Council of Associations of Social Educators), (CEES). This culminated in the publication of the Código Deontológico y el Catálogo de Funciones y Competencias de la Educadora y el Educador Social ( Code of Ethics and the Catalogue of Roles and Responsibilities of the Social Educator), and named "Documentos Profesionalizadores" (Professionalizing Documents).

These documents define social education as the right of all citizens, while the profession of social educator is considered pedagogical in nature, working to generate educative contexts, provide channels and training which enable people to live in society, and promote cultural and social activities (ASEDES, 2007: 11 et seq.). However, it should be noted, that this document was created knowing that it is incomplete and which is, therefore, open to new ideas

NARRACIONES DE DERECHOS:EDUCACIÓN SOCIAL, ÉTICA Y DEONTOLOGÍA PROFESIONAL [ 313 ] SIPS - PEDAGOGÍA SOCIAL. REVISTA INTERUNIVERSITARIA [1139-1723 (2012) 20, 303-323] • TERCERA ÉPOCA 
bilidad de todos los seres humanos, de nuestras acciones, ya que es premisa fundamental para el abordaje de acciones tendentes a la consecución de un mundo mejor. Y para aproximarse a estos fines creemos que no podemos mantener posturas que abandonen a su suerte a las personas con las que trabajamos, sino que es necesario mantener un compromiso social y político.

No cabe duda que en la sociedad en la que nos desarrollamos, es necesario mantener una constante reflexión y actitud ética ante los acontecimientos que nos rodean. Esta actitud y reflexión debe girar en torno a la persona, como tal, y también, como profesional. Por lo tanto, parece necesario un razonamiento ético vinculado a ideas tan necesarias para el desarrollo humano, como la libertad, la responsabilidad, la identidad, la convivencia y con tantos otros valores necesarios para el desarrollo humano. Al vincular esta reflexión con la profesión de educador/a social, la percibimos como ineludible, ya que trabajamos con una población que mantiene una problemática social y existencial que la hacen convertirse en personas en desventaja. Pero la manera de enfrentarnos a estas situaciones no debe ser desde el individualismo profesional, bien intencionado, pero también relativo, sino desde una reflexión ética emanada desde el colectivo profesional, surgiendo así, el denominado código deontológico que orienta nuestras acciones, emanadas de la educación social, ya que solemos enfrentarnos a situaciones que exigen proceder con justicia, responsabilidad y eficacia ante situaciones determinadas, para que las personas con las que trabajamos sean iguales en derechos y deberes.

Desde estos planteamientos nace el Código Deontológico de las/os educadoras/es sociales que define los fines de la profesión, guiando nuestras acciones, fijando unas normas inquebrantables de la profesión, colaborando en el desarrollo de las acciones educativas que abordamos. Pero estas cuestiones no pueden ni deben estar cerradas, por lo que el código and contributions for improvement. Furthermore, ethics is presented as a basic component of accepting responsibility for our actions, or, rather, a collective responsibility, this being a fundamental premise for the aims to achieve a better world. In order to attain these goals, we believe we cannot support a posture that abandons people with whom we work, rather, that it is essential to be both socially and politically commited.

There is no doubt that in today's society, we need to maintain an attitude which is both ethical constantly critical of events happening around us. This attitude should be applied to individuals, as such, and individuals as professionals. Therefore an ethical reasoning appears needed, linked to ideas which are essential for human development, such as freedom, responsibility, identity, and coexistence, among the many other factors of equal important in obtaining this end. Consequently, it inevitable to link this idea to the job of social educator, since we work with those who suffer social and existential difficulties, which, in turn, renders them disadvantaged. The way to manage this situation should not be from an individualistic professional attitude, however well-meaning, although, at the same time, relative, but rather from an ethical standpoint, emanating from the professional collective and giving rise to the deontological code which guides our actions, arising from social education. This, since we frequently face situations which require us to act fairly, responsibly and efficiently, to ensure that the people with whom we work are equal in terms of rights and obligations.

From these ideas the Code of Ethics of Social Educators arose, which defines the purposes of the profession, guides our actions, sets strict standards and collaborates with the development of the educational tasks we undertake. Notwithstanding, these 
deontológico permanece abierto a reflexión y aportaciones, ya que no debe considerarse como unas reglas de actuación impuestas, sino que emana de la reflexión profesional que debe considerarse una guía que aclara y libera la profesión de la educación social.

En cualquier caso, nuestro código deontológico supone la aceptación de unas normas, de una manera de actuar que se basan en unos principios éticos aceptados y que, de algún modo ayudan al planteamiento y consecución de unos objetivos y acciones.

Así, el Código Deontológico de la Educadora y el Educador Social, recoge los siguientes principios (ASEDES, 2007: 24):

- Principio de respeto a los Derechos Humanos. El educador/a social actuará siempre en el marco de los derechos fundamentales y en virtud de los derechos enunciados en la Declaración Universal de los Derechos Humanos.

- Principio de respeto a los sujetos de la acción socioeducativa. El educador/a social actuará en interés de las personas con las que trabaja y respetará su autonomía y libertad.

- Principio de justicia social. La actuación del educador/a social se basará en el derecho al acceso que tiene cualquier persona que viva en nuestra comunidad, al uso y disfrute de los servicios sociales, educativos y culturales en un marco del Estado Social Democrático de Derecho y no en razones de beneficencia o caridad.

- Principio de profesionalidad. La autoridad profesional del educador/a social se fundamenta en su competencia, su capacitación, su cualificación para las acciones que desempeña, su capacidad de autocontrol y su capacidad de reflexión sobre su praxis profesional.

- Principio de la acción socioeducativa. El educador/a social es un profesional de la educación que tiene como función básica la creación de una relación educativa que facilite a la persona ser protagonista issues cannot, and should not, be closed to change. The code of ethics is open to discussion and input, and should not be considered imposed rules of action, but as a guide produced from professional deliberations, that clarifies and liberates social education.

In whatever case, our code of ethics constitutes an acceptance of rules, a way of acting that is based on approved ethical principles and, in some way, helps in the broaching and achievement of objectives and actions.

Thus, the Código Deontológico de la Educadora y el Educador Social includes the following principles (ASEDES, op.cit.: 24 et seq.):

- Principle of respect for human rights. The social educator will always act within the framework of the fundamental rights enshrined in the Universal Declaration of Human Rights.

- Principle of respect for the receivers of educational action. The social educator acts in the interests of the people with whom they work and respect their autonomy and freedom.

- Principle of social justice. The work of the social educator is based on the right of access to education by all community members, the free use of social, educational and cultural services based on the social and democratic rule of law and not on reasons of welfare or charity.

- Principle of professionalism. The professional authority of the educator is based on their social competence, training, capacity for duties, self-control and the ability to reflect on their professional practice.

- Principle of socio-educational action. The basic function of the professional educator is to create an educational relationship which helps a person achieve autonomy over their own life. In addition, the teacher, in all his socio-educational actions, is of the conviction that

NARRACIONES DE DERECHOS:EDUCACIÓN SOCIAL, ÉTICA Y DEONTOLOGÍA PROFESIONAL [ 315 ] SIPS - PEDAGOGÍA SOCIAL. REVISTA INTERUNIVERSITARIA [1139-1723 (2012) 20, 303-323] • TERCERA ÉPOCA 
de su propia vida. Además, el educador/a social en todas sus acciones socioeducativas, partirá del convencimiento y responsabilidad de que su tarea profesional es la de acompañar a la persona, al grupo y a la comunidad para que mejoren su calidad de vida, de manera que no le corresponde el papel de protagonista en la relación socioeducativa, suplantando a las personas, grupos o comunidades afectadas. Por esto en sus acciones socioeducativas procurará siempre una aproximación directa hacia las personas con las que trabaja, favoreciendo en ellas aquellos procesos educativos que les permitan un crecimiento personal positivo y una integración crítica en la comunidad a la que pertenecen.

- Principio de autonomía profesional. El educador/a social tendrá en cuenta la función social que desarrolla la profesión al dar una respuesta socioeducativa a ciertas necesidades sociales según unos principios deontológicos generales y básicos de la profesión, que tendrá como contrapartida la asunción de las responsabilidades que se deriven de sus actos profesionales. - Principio de la coherencia institucional. El educador/a social conocerá y respetará la demanda, el proyecto educativo y reglamento de régimen interno de la institución donde trabaja.

- Principio de la información responsable y de la confidencialidad. El educador/a social guardará el secreto profesional en relación con aquellas informaciones obtenidas, directa o indirectamente acerca de las personas con las que trabaja.

- Principio de solidaridad profesional. El educador/a social mantendrá una postura activa, constructiva y solidaria en relación con el resto de profesionales que intervienen en la acción socioeducativa.

- Principio de la participación comunitaria. El educador/a social promoverá la participación de la comunidad en la la- their responsibility, in carrying out their functions, is to guide the person, group and community towards an im proved quality of life. Nevertheless, this does mean that educators play the leading role on the socio-educational situation, supplanting the affected persons, groups or communities. It follows, therefore, that in their socio-educational actions, educators will always seek direct contact with the people with whom they work and encourage those educational processes which provide positive personal growth and critical integration into the community.

- The principle of professional autonomy. The social educator will take into account the social function undertaken by the profession, which gives a socioeducational response to certain social needs and according to the general, basic ethical principles of the profession, and which, moreover, is to be counterbalanced by the assumption of the responsibilities arising from their professional actions.

- Principle of institutional coherence. The educator will know and respect the wishes, the educational project and internal regulations of the institution in which he works.

- Principle of responsible reporting and confidentiality. The social educator is to observe professional secrecy with regard to information obtained directly or indirectly concerning the people with whom they work.

- Principle of professional solidarity. The educator shall maintain an active stance, and at the same time be constructive and supportive in their relations with other professionals involved in educational action.

- Principle of community participation. The educator shall promote community participation in educational

[ 316 ] - Víctor Manuel Martín Solbes y Eduardo Salvador Vila Merino SIPS - PEDAGOGÍA SOCIAL. REVISTA INTERUNIVERSITARIA [1139-1723 (2012) 20, 303-323] • TERCERA ÉPOCA 
bor educativa, intentando conseguir que sea la propia comunidad con la que interviene, la que busque y genere recursos y capacidades para transformar y mejorar la calidad de vida de las personas.

- Principio de complementariedad de funciones y coordinación. El educador/a social, al trabajar en equipos y/o redes, lo hará de una forma coordinada. Será consciente de su función dentro del equipo, así como de la posición que ocupa dentro de la red siendo consciente de la medida en que su actuación puede influir en el trabajo del resto de los miembros, del propio equipo y de los profesionales o servicios.

Desde estos principios deontológicos el profesional de la educación social debe realizar sus intervenciones, aunque, por tratarse de una profesión relativamente joven, implementada en innumerables ámbitos laborales, cuyos profesionales proceden de una tradición y experiencia laboral, unos, mientras que otros acceden a la profesión desde un reconocimiento formativo universitario, la situación resulta algo compleja.

En cualquier caso, y en nuestra opinión, el Código Deontológico de las Educadoras y Educadores Sociales, carece, al menos, de un principio que podría denominarse: Principio de actuaciones desde, para y por la noviolencia. Creemos que cualquier proceso tendente a la transformación social debe estar presidido por acciones vinculadas con procesos pacíficos de convivencia y con la noviolencia, que desde luego, se alejan mucho de los procesos y planteamientos sociopolíticos de inclusión vigentes en nuestras sociedades. Sentimos la necesidad de que la educación social y desde el compromiso profesional se acometan acciones vinculadas a los derechos humanos, tendentes a la igualdad, a la justicia, a la paz y a la no-violencia, a la consecución de la ciudadanía, a la democracia, en definitiva. Así, cada miembro work, aiming to get the community itself to be the one who participates, seeks and generates resources and skills in order to transform and improve quality of life.

- Principle of complementarity functions and coordination. The social educator will coordinate when working in teams and / or networks. They will be aware of their role within the team, as well as their position within the network. They will also be aware of the extent to which their actions can influence the work of the other members of their own team, professionals or services.

The social educator, then, should base their educational work on these principles. However, the profession is relatively new and undertaken in many different work environments. Additionally, since some practitioners have gained experience through work, whilst others have had university training, a somewhat complex situation arises

This being said, in our opinion the Code of Ethics lacks at least one principle that could be called Principle of Actions arising from, and for, Non-Violence. We believe that whatever action is taken leading to a change in society, it should be undertaken in accord with principles linked to peaceseeking processes of coexistence which, without doubt, are far from the socio-political processes and the ideas prevelant in contemporary society. We feel it is necessary that social education and professional commitment should act in accord with the concepts of human rights, equality, justice, peace, non-violence, citizenship and democracy. Thus, each member of society has a representation of reality that is associated with a prior ideological approach. This is precisely where projects for the change and transformation of society by social educa-

NARRACIONES DE DERECHOS:EDUCACIÓN SOCIAL, ÉTICA Y DEONTOLOGÍA PROFESIONAL [ 317 ] SIPS - PEDAGOGÍA SOCIAL. REVISTA INTERUNIVERSITARIA [1139-1723 (2012) 20, 303-323] • TERCERA ÉPOCA 
de la sociedad mantiene una representación de la realidad que se encuentra asociada a un previo planteamiento ideológico. Y es ahí donde deben originarse proyectos de intervención socioeducativa para el cambio y la transformación social, ya que la praxis de la educadora y del educador social debe originarse tras el planteamiento de profundas reflexiones sobre estos valores que guían nuestra acción. Del mismo modo, a través de estas reflexiones, vehiculadas desde la educación social, creemos que se deben realizar aportaciones que permitan cambiar la realidad en la que vivimos; iniciando una vía de intervención integral y permanente con las personas y colectivos para que asuman responsabilidad, dando, de alguna manera, respuestas a la urgente necesidad de una acción educativa en los entornos segregados y excluidos. Asimismo, desde la educación social, pretendemos abordar los factores culturales, sociales y educativos que ayuden a las personas a dejar de percibirse a sí mismas como integrantes de colectivos excluidos. Y en todo este proceso, la educación social debe aportar conocimientos que se interioricen, para que las personas se conciencien pacíficamente de sus vidas, de su futuro, para que así, y desde su propia concienciación, sean capaces de acometer los procesos de inclusión.

\section{Concluyendo: la educación social como proyecto vigente de transformación social}

En las coordenadas neocapitalistas en las que nos movemos, el vivir juntos no es una consecuencia directa del orden social, sino que se ha convertido en un anhelo que debe ser construido socialmente. Así, no es extraño percibir acontecimientos teñidos de un individualismo asocial, en un entorno de fundamentalismo autoritario caracterizado por la negación política de la sociedad. De este modo, los cambios sociales de nuestras complejas sociedades propician procesos de cambio y re- tors should originate, since educators' codes of practice should be grounded in deep reflections concerning those values which guide our actions. Furthermore, it is through these reflections, transmitted through social education, that we can attempt to provide opportunities with which to change the reality. Since we aim, through comprehensive and permanent intervention, to encourage people and groups to assume responsibility, which, in a way, provides an answer to the urgent need for educational action directed towards those groups experiencing segregation and exclusion. In the same way, through social education, our aim is to address cultural, social and educational factors that help individuals to avoid considering themselves members of excluded groups.

3. Conclusion: social education as a valid force for social change

In our neocapitalist times, coexistence is not a direct consequence of social order, but an objective to be constructed by society. Thus, it is not unusual to find events of an asocial, individualistic nature occurring in an authoritarian, fundamentalistic environment, characterized by the political negation of society. In this way, changes in our society encourage processes of renovation which demand ideas with which to face these challenges. Theseconcepts in- 
novación que exigen planteamientos para afrontar desafíos. Así, la lucha contra la exclusión, la mejora de la convivencia, los procesos que llevan a la consecución de la paz, la búsqueda de la igualdad y de la justicia social, y la consecución de una cultura de bienestar, entendida como conciencia colectiva orientada al establecimiento de nuevas formas de convivencia, basada en valores fundamentales como la libertad, la igualdad, la justicia y el pluralismo democrático (López, 2000), huyendo del concepto de asistencialismo basado en Estados-Providencia (Rosanvallón, 1995), para llegar a un modelo participativo de toda la ciudadanía basado en procesos pedagógicos.

La instauración hegemónica del modelo neoliberal, ha generado conflictos y tensiones socioeconómicas y políticas, que ha producido una economía globalizada que hace emerger una cultura mercantilista que conduce al debilitamiento de las identidades individuales y colectivas, a los procesos de exclusión y vulnerabilidad social. Por lo tanto, creemos que es imprescindible recobrar el impulso clásico, basado en procesos democráticos, vinculando no sólo a los que están al margen de la plena ciudadanía, sino también, que engloben a los desinteresados en la participación cívica, porque como nos recuerda Habermas (2002), en su perfeccionamiento, el capitalismo se autorregula mediante procesos de despolitización que impiden un desarrollo democrático participativo.

No cabe duda de las perversas consecuencias de los efectos de la globalización y de las relaciones mercantilistas derivadas de los estados capitalistas, como son el individualismo, la insolidaridad, la intolerancia, la falta de diálogo, la falta de cohesión social, la privatización, el no respeto a la identidad ajena, a lo diferente, a lo minoritario, que han marcado y aún marcan, las relaciones interpersonales en nuestras sociedades. Estos valores, o la falta de ellos, son, además, defendidos en nuestras modernas sociedades de manera eficaz por nuestros gobiernos que no clude: the fight against exclusion; improvements to coexistence; the undertaking of peace-seeking processes; the search for equality, social justice and a culture of general welfare, understood to be the collective conscience leaning towards the establishment of new ways of coexisting based on fundamental values such as liberty, equality, justice and a democratic pluralism (Lopez, 2000). All far from the the concept of welfare based on the ideas of the welfare state (Rosanvallon, 1995), in order to attain a participatory model of citizenship, based on educational processes.

The hegemonic implementation of the neoliberal model has led to socioeconomic and political conflicts and has produced a globalized economy with a market culture. This has given rise to a weakening of individual and group identities, processes of exclusion and a sense of social vulnerability. Therefore, we consider it essential to resort again to classical concepts based on democratic processes, linked not only to those who are outside full citizenship, but also to those who are disinterested in civic participation. Moreover, as Habermas (2002), reminds us, capitalism, in its development, is self-regulating through processes of depolitisation which impede participatory democratic development.

There is no doubt about the negative consequences of globalization and the mercantile relations arising from capitalist states. These consequences have marked and continue to mark our societies, and have given rise to tendencies towards individualism, insolidarity, intolerance, as well as the lack of dialogue, lack of social cohesion, respect for others and for those who are different or in a minority. Moreover, these values, or rather lack of them, are defended extremely effectively in modern society by our governments, who lose no opportunity to con- 
pierden ninguna oportunidad para cantar los parabienes de las mismas y reproducir una y otra vez los procesos de injusticia y exclusión social. Por otra parte nuestras sociedades son las únicas imaginables y las mejores posibles, según los parámetros en los que nos movemos, por lo que, desde estas posiciones, no tenemos necesidad de aventurar cambios. Así, como ya indicamos, nuestras sociedades, autoproclamadas inclusoras, no hacen más que reproducir situaciones que propician la exclusión y para paliar estas situaciones, acometen las consecuencias de estos procesos a través de profesiones como la nuestra, desde la educación social, en lugar de abordar los orígenes de los problemas, esto es la injusticia social, las situaciones de marginación, pobreza y exclusión que producen el propio desarrollo de nuestras sociedades. Así, los colectivos sociales económicamente poderosos, investigan e invierten bienes y mano de obra para conseguir situaciones que les permita vivir mejor. En cambio, las sociedades pobres, no pueden investigar, ni invertir bienes, ni mano de obra para conseguir estas mejoras en las formas de vida, lo que hace que nuestras sociedades se quiebren, y se constituyan en dos grupos, las que avanzan a nivel económico y las que no lo hacen; las que son ricas y las que son pobres. Las pobres, evidentemente, pronto dejan de contar y solo se acude a ellas, o para su explotación o para desarrollar políticas asistencialistas, que en nada resuelven sus problemas, aunque sí proporcionan a las sociedades que asisten, un gran bienestar, porque desde nuestra posición de poder y riqueza hacemos algo por los demás, sin que cambie el estatus quo actual. Además, el desarrollo de las sociedades poderosas y ricas, genera en su propio seno, bolsas de pobreza y exclusión, que se abordan de la misma manera, esto es, desde el asistencialismo. Estas situaciones se reproducen una y otra vez, y con el pasar de los años se enquistan, de manera que el estado asistencialista se conforma con asistir a estos grupos, gratulate themselves and repeat over and again processes of injustice and exclusion. On the other hand our societies are the only ones imaginable and the best possible within the parameters in which we move, which is why, from this position, we have no need to venture changes. As previously stated, our societies, self proclaimed as inclusive of all peoples, only give rise to situations conducive to exclusion. To remedy the consequences of these situations, professions such as that of social educator are called on, instead of finding a remedy for the causes, those of social injustice, discrimination, poverty and exclusion, all produced by the development of our societies. Economically powerful social groups are able through their wealth to undertake investigation, invest goods and employ labour with which to obtain a higher standard of living. Poor societies, however, are not able to carry out investigation, nor invest goods, nor use labour to obtain these improvements. As a consequence, our societies are fractured and two groups are formed, those who progress economically and those who do not; those who are rich and those who are poor. The poor, of course, will soon no longer count and are only necessary for their exploitation or when welfare policies need to be enforced. Providing welfare does not solve their problems, although it does give a feeling of well-being to those who offer help, since from our position of power and wealth, we can do something for others without changing the status quo. Furthermore, the development of powerful and wealthy societies generates within itself pockets of poverty and exclusion, a problem which is addressed in the same way, that is, employing welfarism. This occurs time and again, eventually producing a festering situation where the welfare state is content to assist those groups and, what is worse, assisted 
y lo que es peor aún, los colectivos asistidos, se acostumbran y se conforman con ser asistidos. Sin lugar a dudas, estas situaciones producen un gran malestar social y es necesario abordar las causas que las determinan, más que abordar sus consecuencias.

Y en el abordaje de estas situaciones, la educación social se presenta como herramienta pedagógica de transformación social a través de procesos de empoderamiento ciudadano preñados de ética profesional. Se trata de que las sociedades democráticas generen en las personas actitudes de compromiso con las otras personas, para así hacer corresponsables a todos y todas del bienestar general, teniendo en cuenta el equilibrio necesario entre la construcción de la identidad y la gestión de la diversidad, porque como nos recuerda Caride (2002), se trata de "COhesionar a personas y sociedades en torno a iniciativas y valores que promuevan una mejora significativa del bienestar colectivo, ..., de lo que se deduce y espera que ha de ser una educación que debe hacerse en, con, por y para la sociedad". Por lo que no es solo necesario trabajar con las personas y colectivos desfavorecidos para lograr su inclusión, sino que es necesario trabajar educativamente también con las personas incluidas y los/las profesionales de la educación social a través de códigos éticos bien definidos, realizando una apuesta decidida por la lucha en favor de los derechos humanos, porque como nos recuerda Enrique Dussel (2001):

No es necesario inventar cosas. Se trata de partir de lo negado: no comen, hay que ver cómo comer; no tienen vestido, hay que ver cómo lograr el vestido; no tienen casa, hay que lograrla; no tienen cultura o autoafirmación de su propia identidad (que, por supuesto, se construye, no está dada), pues hay que construirlas. No hay que pensar en utopías educativas, hay que partir de las víctimas y su negatividad. La utopía es la afirmación de esa negatividad como positividad. groups get accustomed to this state and conform with being assisted. Undoubtedly, these situations cause great social unrest and the causes, rather than the consequences, must be addressed.

In dealing with these situations, social education is presented as a tool for social change through citizen empowerment processes influenced by professional ethics. It is necessary for democratic societies to generate attitudes of solidarity, to encourage all to be responsible as a group for the well-being of others, taking into account the necessary balance between the construction of identity and diversity management. As Caride (2002) states, the issue is to "unite peoples and societies following initiatives and values that promote a noticeable improvement in social welfare.... and this must necessarily come from an education system which works in, with and for society. It is not enough to solely work for the inclusion of disadvantaged persons or groups, but also to educate those that are already included in society by means of a social education with well-defined ethical codes that are clearly in favour of promoting human rights. As Enrique Dussel (2001), writes:

It is not necessary to invent things. The question is to start from what is denied: they do not have food, food must be found; they have no clothes, clothes must be sought; they have no house, one must be obtained; they have no culture or self-esteem (which, of course, is gained, not given), then it must be acquired. One must not think in educational utopias, but must start from the victims and their negativity. Utopia is the assertion of this negativity as positivity.

NARRACIONES DE DERECHOS:EDUCACIÓN SOCIAL, ÉTICA Y DEONTOLOGÍA PROFESIONAL [ 321 ] SIPS - PEDAGOGÍA SOCIAL. REVISTA INTERUNIVERSITARIA [1139-1723 (2012) 20, 303-323] TERCERA ÉPOCA 


\section{Referencias bibliográficas / References}

Arendt, H. (1993). La condición humana. Barcelona: Paidós.

Arendt, H. (1996). Entre el pasado y el futuro. Barcelona: Península.

Asedes (2007). Documentos profesionalizadores. Barcelona: ASEDES.

Bárcena, F. (1994). La práctica reflexiva en educación. Madrid: Complutense.

Barton, L. (1998). Discapacidad y sociedad. Madrid: Morata.

Camps, V. y Giner, S. (2001). Manual de civismo. Barcelona: Ariel.

Caride, J.A. (2002). Construir la profesión: la educación social como proyecto ético y tarea cívica. En Pedagogía Social. Revista Interuniversitaria, $\mathrm{n}$ ㅇ. 9: Entre el profesionalismo y el voluntariado.

Caride, J.A. (2002). La Pedagogía Social en España, en Núñez, V. (coord): La educación en tiempos de incertidumbre: las apuestas de la Pedagogía Social. Barcelona: Gedisa.

Cortina, A. (2006). Educación en valores y ciudadanía. En Martínez, M. y Hoyos, G. (coords.): La formación en valores en sociedades democráticas. Barcelona: Octaedro.

Delors, J. (1996). La educación encierra un tesoro. Informe a la Unesco de la Comisión Internacional sobre educación para el siglo XXI. Madrid: Santillana-UNESCO.

Durston, J. (1999). Construyendo capital social comunitario. Una experiencia de empoderamiento comunitario en Guatemala. Santiago de Chile: CEPAL.

Durston, J. (2001). Capital social, parte del problema,. Parte de la solución. Santiago de Chile: CEPAL.

Dussel, E. (2001). La ética, en III Congreso de Educación Social. Barcelona.

Dussel, E. y Apel, K.O. (2005): Ética del discurso, ética de la liberación. Madrid: Trotta.

Freire, P. (1970). Pedagogía del oprimido. México: Siglo XXI.

Freire, P. (1990). La naturaleza política de la educación. Cultura, poder y liberación. Barcelona: Paidós.
Freire. P. (1993). Pedagogía de la esperanza. México: Siglo XXI.

Freire, P. (1997). A la sombra de este árbol. Barcelona: El Roure.

Freire, P. (1998). Pedagogía de la autonomía. México: Siglo XXI.

Freire, P. (2002). Educación y cambio, (5 $5^{\underline{a}}$ ed). Buenos Aires: Galerna.

García Canclini, N. (2004). Diferentes, desiguales y desconectados. Barcelona: Gedisa.

Guisán, E. (2001). Valores éticos en la sociedad actual, en III Congreso de Educación Social. Barcelona.

Habermas, J. (1987). Teoría de la acción comunicativa. Madrid: Taurus.

Habermas, J. (2002). Ciencia y técnica como ideo logía. Madrid: Tecnos.

Hirsch, A. (2010). Ética profesional y profesores universitarios, en Reencuentro, $\mathrm{n}^{\mathrm{o}}$. 57. México: Universidad Autónoma Metropolitana-Xochimilco.

Jelin, E. (2003). Más allá de la nación: las escalas múltiples de los movimientos sociales. Buenos $\mathrm{Ai}-$ res: El Zorzal.

López, R. (2000). Fundamentos políticos de la Educación Social. Madrid: Síntesis.

Marshall, T. H. (1950). Ciudadanía y clases sociales. Cambridge: CUP.

Martín, V.M. (2008). Ser ciudadano, sentirse ciudadano, ejercer de ciudadano. De las palabras a los hechos. En Valdivieso, S. y Almeida, A.: Educación y ciudadanía. Las Palmas de Gran Canaria: Anroart. Martín, V.M. y Vila, E.S. (2007). Mapas de exclusión, animación sociocultural y espacios interculturales en la globalización. En Cid, X.M. y Péres, A.: Educación social, animación sociocultural y desarrollo comunitario. Vigo: Universidad de Vigo.

Pantoja, L. (1998). Nuevos espacios de la Educación Social. Bilbao: Universidad de Deusto.

Pérez, P. (2008). La formación de la ciudadanía. La educación para la ciudadanía. En Valdivielso, S. y Almeida, A. (eds): Educación y ciudadanía. Las Palmas de Gran Canaria: Anroart.

Rappaport, J. (1987). Terms of empowerment/ exemplars of prevention: toward a theory of Community Psichology. American Journal of Community Psichology, nº. 15: 121-148.

[ 322 ] Víctor Manuel Martín Solbes y Eduardo Salvador Vila Merino SIPS - PEDAGOGÍA SOCIAL. REVISTA INTERUNIVERSITARIA [1139-1723 (2012) 20, 303-323] - TERCERA ÉPOCA 
Riera, J. (1998). Concepto, formación y profesionalización de: el educador social, el trabajador social y el pedagogo social. Un enfoque interdisciplinar e interprofesional. Valencia: Nau Llibres.

Rosanvallón, P. (1995). La nueva cuestión social. Repensar el Estado-Providencia. Buenos Aires: Manantial.

Rowlands, J. (1997). Questioning empowerment. Oxford: Oxfam.

Rubio-Carracedo, J.; Rosales, J.Mํㅜ․ y Toscano, M. (2002). Retos pendientes en ética y política. Madrid: Trotta.

Rubio-Carracedo, J.; Rosales, J.Mํㅗ․ y Toscano, M. (dirs): (2009). Democracia, ciudadanía y educación. Madrid: Akal.

Sáez, J. (2003). La profesionalización de los educadores sociales. En busca de la competencia educativa cualificadora. Madrid: Dykinson.

Sartori, G. (1992). Elementos de teoría política. Madrid: Alianza.

Savater, F. (1999). Ética y ciudadanía. Caracas: Monte Ávila.

Sousa Santos, B. (2005). El milenio huérfano. Madrid: Trotta.

Souza, H. (1994). Ética y ciudadanía. Sao Paulo: Moderna.

Tedesco, J.C. (2003). Los pilares de la educación del futuro. Barcelona: FUOC.

Vigotsky, L.S. (2000). El desarrollo de los procesos psicológicos superiores. Barcelona: Crítica.

Vila, E.S. (2005). Ética, interculturalidad y educación democrática. Huelva: Hergué.

Villarini, A.R. (2004). El desarrollo humano integral a base de competencias. San Juan de Puerto Rico: Biblioteca del Pensamiento Crítico.

Yurén, T. (2005). Educación para la eticidad y la ciudadanía en tiempos de globalización. En Oraisón, M. (coord): Globalización, cudadanía y educación. Barcelona: Octaedro.

\section{DIRECCIÓN DE LOS AUTORES /}

\section{AUTHORS' ADDRESSES:}

Víctor Manuel Martín Solbes y Eduardo Salvador Vila Merino. Universidad de Málaga. Departamento de Teoría e Historia de la Educación. Facultad de Ciencias de la Educación.

Tfno: 952132584

Correo electrónico/e-mail:

victorsolbes@uma.es, eduardo@uma.es

Fecha de recepción del artículo/

reveived date: 8 .VII.2010

Fecha de revisión del artículo/

reviewed date: 12.VII.2010

Fecha de aceptación final/

accepted date: 17.X.2010

\section{COMO CITAR ESTE ARTÍCULO /}

\section{HOW TO CITE THE ARTICLE:}

Martín Solbes, V. M. y Vila Merino, E. S. (2012). Narraciones de derechos: Educacion Social, Etica y Deontologia profesional. Pedagogia Social. Revista Interuniversitaria, 20, pp. 303-323.

Martin Solbes, V. M. \& Vila Merino, E. S. (2012). Narratives on human rights: social education, ethics and professional deontology. Pedagogia Social. Revista Interuniversitaria, 20, pp. 303-323. 